\title{
Availability of Innovative Instructional Media for Social Studies Implementation in Enugu State
}

\author{
C. Ugo Anthonia ${ }^{1} \&$ U. Nweke Francisca ${ }^{2}$ \\ ${ }^{1}$ Department of Educational Foundations, Godfrey Okoye University, Enugu, Enugu State, Nigeria \\ ${ }^{2}$ Department of Curriculum and Instruction, Federal College of Education, Yola, Adamawa State, Nigeria \\ Correspondence: C. Ugo Anthonia, Department of Educational Foundations, Godfrey Okoye University, Enugu, \\ Enugu State, Nigeria. Tel: 234-81-6022-8078. E-mail: sisterchinweugo@gmail.com
}

Received: February 19, 2020

doi:10.5430/irhe.v5n1p25
Accepted: March 24, 2020

Online Published: March 29, 2020

URL: https://doi.org/10.5430/irhe.v5n1p25

\begin{abstract}
The study investigated the availability of innovative instructional media for social studies implementation in Enugu State. The study adopted the descriptive survey research design. Two research questions and two hypotheses guided the study. The population for the study consisted of 339 social studies teachers from the six education zones in Enugu State. There was no sample because of the manageable size of the population. The instrument for data collection was a structured questionnaire. Instrument was face validated and reliability was obtained using Cronbach alpha. Data were analyzed using mean, standard deviation for the research questions and $t$ - test statistics for the hypotheses. Findings from the study revealed that teachers in urban and rural schools were provided with instructional media for the implementation of social studies curriculum to a very low extent. Teachers in urban secondary schools employed innovative instructional methods to a great extent while those in rural schools employed innovative teaching methods in the implementation of social studies curriculum to a low extent. The study recommended that efforts should be made by school administrators to expose teachers to workshops on innovative methods of teaching and the use of instructional media. Principals of schools should monitor the teaching of social studies, with a bid to ensure use of provided instructional media and innovative instructional strategies.
\end{abstract}

Keywords: innovative teaching methods, availability, instructional media, implementation, social studies

\section{Introduction}

The all-round development of any nation depends largely on the effective implementation of the educational curriculum. Generally, quality education invests man with the ability and opportunities for self - realization and the understanding of the environment around him (Ogakwu, 2010). The Nigerian Educational Research and Development Council (NERDC, 2013) came up with the curriculum of Social Studies in such a way that it has the potentials to equip the learners with the needed skills to survive in the environment. Dhandhania (2016) opined that the reason among others, of introducing social studies in Nigeria is to help learners interact with their cultural, social and physical environment, appreciate community life and national heritage, develop characters, values and attitudes expected for national integration and to develop skills to express ideas among one another. Onyeanusi (2016) reported that in a community of people populated with diverse multiple culture like Nigeria, they need to be exposed to the values to care and tolerate each other. Mezieobi (2007) and Mezieobi, Fubara and Mezieobi (2013) had opined that the essence of social studies instruction in junior secondary school is to equip the learners with attitudes, values, knowledge, and skills for functional living in Nigerian society. Hence incorporating social studies in the school curriculum guarantees well - rounded education for learners (Dhandhania, 2016). The significant function social studies play requires effective implementation to enhance students understanding.

Factors identified to be responsible for students understanding of the principles and concepts underlying social studies lessons, among others, are the use of instructional media and innovative teaching methods. The availability of instructional media, facilities and resources in educational teaching and learning stands out among others as a powerful measure for a successful actualization of any curriculum implementation. It is necessary for present day social studies teachers to direct learning with instructional media. The term instructional materials mean all the resources which are within the reach of the teacher and the student, put to use in order to facilitate teaching and learning. Hence, it follows that such resources could be human and non-human in as much as they facilitate the 
process of acquiring and evaluating knowledge, skills, attitudes, moral and value (Inyang-Abia, 2004). In social studies classroom, some resources and instructional media are recommended to be always part of the teaching and learning in order to enrich the strategic processes required for quality teaching. They include: text books; audio visual material; graphics or two-dimensional materials; community resources etc.

The use of instructional media in teaching social studies provides an additional resource which must be integrated into the total learning experience (Ajewole, 2005). The use of appropriately selected instructional media and facilities by the teacher at all levels promote effective teaching and learning. Resources to be used for effective learning should include those that are capable of making permanent impressions on the minds of the learners (Edinyang \& Effiom, 2017). Instructional media such as audio visual (television, radio, video, film, DVD, computer assisted power point) etc. are capable of impacting permanent knowledge on learners. Provision of instructional media is extremely necessary to improve the quality of learning in the classroom. It is obvious that teaching and learning social studies cannot be accomplished effectively without the use of instructional materials that incite reform by conveying knowledge and information to learners. But it has been identified that unavailability of instructional media is still a big challenge in teaching social studies (Eya \& Ureme 2011). This could mean that teachers who teach social studies are either not provided with adequate instructional media or that they teach without them. Social studies which is a core discipline for all and basic discipline for national development has as one of its objectives to set right the wrongs of the society. So, it becomes imperative for teachers' teaching strategies to reflect the targets of curriculum designers (Arthur, 2012).

The nature and objectives of social studies require suitable innovative teaching methods to teach the subject effectively in the schools. Teaching methods are strategies employed by teachers for the delivery of pedagogical instruction of social studies in schools. Mezieobi in Okobia (2016) expressed that the current practice whereby social studies teachers rely on the didactic and expository methods in their instruction does not augur well for implementation of social studies curriculum. Given the nature of social studies and in order to accomplish impactful learning Mezieobi (2008), Adeniran (2014) and the National Council on Social Studies (NCSS) (2004) have often recommended instructional methods that places the learner at the center of the social studies teaching and learning for the successful implementation of the social studies curriculum. Various studies have shown that innovating student centred methods are superior to the teacher-dominated behaviorist instructional model that rely on lectures, textbooks, assignments and traditional tests (0kobia, 2016). If suitable methods are not used in teaching, curriculum implementation will not be realized (Okogu, 2011). Therefore, to teach the curriculum effectively, requires the use of suitable and innovative teaching methods by the teacher (Mezeobi, 2008). For Nigeria, like other developing countries, to have a functional and quality education system, it must constantly endeavor to provide quality instructional media and ensure innovative teaching strategies are adopted. Lack of these, hinder the effective implementation of social studies curriculum in Nigerian schools (Mezieobi \& Onyeanusi, 2012). This study contributes to the limited literature on the use of instructional media and the debate on the effectiveness of innovative teaching approach. The study is specially designed to provide empirical evidence on the abundance and utilization of instructional media and innovative teaching strategies in Nigeria, with special focus on Enugu state and teaching of social studies in secondary schools in the state. The study worries that lack of such empirical evidence crates a gap between understanding and creating a solution for effective implementation of the social studies curriculum in Nigeria.

\section{Statement of the Problem}

It is a common knowledge that a well-planned and developed curriculum can only be meaningful if translated into action through effective implementation. Ensuring effective curriculum implementation involves among others the use of instructional media and innovative teaching method. Teaching method is a major concern that affects the attainment of education goals. It is observed that the old method of teaching which is teacher centered is still largely been used in schools in most developing countries and with limited instructional media for effective teaching and learning. A major worry of this study is that the lack of instructional media affects teaching such that the teaching of social studies is more theoretical than practical, as it is in some regions in most developing countries and in Enugu state. This study is poised at investigating the availability of instructional media and the teaching methods both in urban and rural junior secondary schools in Enugu State.

\section{Purpose of the Study}

The purpose of this study is to investigate the extent the availability of innovative instructional media in the implementation of social studies in Enugu State. Specifically, the study sought to investigate the extent to which teachers in secondary schools; 
1. are provided with instructional media for implementation of social studies curriculum.

2. employ innovative instructional methods in the implementation of social studies curriculum.

\section{Research Questions}

1. To what extent are teachers in urban and rural secondary schools of Enugu State provided with instructional media for implementation of social studies curriculum?

2. To what extent do teachers in urban and rural secondary schools employ innovative instructional methods in the implementation of social studies curriculum?

\section{Theoretical Background}

The study was anchored on Participatory Theory by Jean Lave, Etienne Wanger, Stephen Billet and Paul Hager in 1991. Participatory theory is among the curriculum theories that try to illustrate the relationship between theories of learning and various ways in which they influence pedagogies. Participatory theory is greatly influenced by theories of development as it allows individuals and communities to be subject of their own development. The teaching and learning approach of participatory theory is distribution and collaboration as the learning theory emphasize group activities, working in a team. It is a theory that is practice - centered as emphasizing on modern pedagogy is student centered with activities for learning. It is through these activities, that the learner gains deeper understanding of the intricacies of the task as well as the context in which to apply the knowledge used in solving problems.

Participatory theory is by large applied to social studies education. Social study as a study of man and his environment implies that it is community oriented and activity centered as with participatory theory. Social studies education equips students with the basic skills and social habits which should hold them to fit into the society. Through social studies education, learners become responsible and discipline individuals, capable and willing to contribute to the development of the society. Using participatory theory, learners are involved in decision making and democracy practice.

\section{Area Description}

The area of the study is Enugu State. Enugu state is at the centre of Eastern states of Nigeria. Enugu State share boundaries with Anambra State to the east, Benue and Kogi States to the North, with Ebonyi State in the west and with Abia/Imo State in the south. The people of Enugu speak Ibo as their major language and are predominantly agrarian. The residents of Enugu State are people from different works of life who value education and the welfare of the society. The Universal Basic Education is practiced throughout Enugu State and secondary schools are established and located in all the urban and rural communities in the state. Social studies is taught in Nigerian secondary schools of which Enugu state is inclusive. There are also a good number of social studies teachers in these schools.

\section{Methodology}

The study adopted descriptive survey research design. According to Okebaram (2014), descriptive survey research gets detailed and factual information about problems and describe them as they are. Osuala (2007) asserts that survey research involves studying both large and small population. This design is suitable for the study because the researchers investigated carefully, drawing the opinion of social studies teachers in secondary schools in Enugu state. The study was carried out in the secondary schools in the six education zones in Enugu State. These education zones are Enugu, Udi, Agbani, Agwu, Nsukka and Obollo - Afor zones. The population comprised of 339 social studies teachers in public junior secondary schools in Enugu State. Enugu has 84, Udi 47, Agbani 41, Agwu 22, Nsukka 86 and Obollo - Afor 59. All the teachers served as respondents for the study because the population was considered manageable. The instrument used for data collection was a questionnaire. The instrument was developed bearing in mind the two research questions thus was divided into two parts: A and B. Part A has 10 items on extent to which teachers in Enugu State are provided with instructional media for the implementation of social studies curriculum and part B also has 10 items for determining the extent to which teachers in urban and rural secondary schools employ innovative instructional methods in the implementation of social studies curriculum. The instrument was developed based on a 4 - point Likert type measuring scale with response options of very great extent (VGE), great extent (GE), low extent (LE) and very low extent (VLE); with numerical values of 4, 3, 2 and 1 respectively. The respondents were requested to tick the option that best matched their response on each of the items. The instrument was face validated by three experts. The reliability of the instrument was determined through a pilot study by administering copies of the questionnaire to 50 teachers located in Anambra state, a state outside the study zone. The data obtained from their responses through the instrument were used in computing the reliability index using 
Cronbach Alpha in order to measure the internal consistency of the items. Reliability indices of 0.71 and 0.80 were obtained for parts A and B; while an overall reliability index of 0.75 was obtained for the entire instrument. The researchers in addition to five research assistants, employed direct delivery technique in the administration of the questionnaire. The research assistants were sent to different zones in the study area. The data collected for this study were analyzed, using mean and standard deviation to address the research questions and t-test to test the null hypotheses. These statistical tools were used because they are suitable for analysis nominally distributed data. The $\mathrm{t}-$ test analysis was used to test the hypothesis at 0.05 significance level. The $t-$ test is appropriate because of its capacity to handle both small and large numbers. If the calculated value of significance is less than 0.05 , then the mean difference is significant and the null hypothesis were accepted as stated.

\section{Results}

Results of the study are presented in line with the research questions and hypotheses that guided the study.

Research Question 1: To what extent are teachers in secondary schools of Enugu State provided with instructional media for implementation of social studies curriculum?

Table 1. Mean ratings and standard deviation of teachers in secondary schools on the extent to which they are provided with instructional media for the implementation of social studies curriculum $(\mathrm{N}=339)$

\begin{tabular}{|c|c|c|c|c|c|c|c|c|c|c|}
\hline $\mathbf{S} / \mathbf{N}$ & Item statements & & Urba & & & Rura & & & Over & \\
\hline & & Mean & SD & Dec & Mean & SD & Dec & Mean & SD & Dec \\
\hline 1 & $\begin{array}{l}\text { Instructional television } \\
\text { provided and used by } \\
\text { studies teachers in schools }\end{array}$ & 1.59 & 0.79 & LE & 1.64 & 0.88 & LE & 1.61 & 0.83 & $\mathrm{LE}$ \\
\hline 2 & $\begin{array}{l}\text { Teachers are provided with } \\
\text { instructional internet facilities to } \\
\text { teach social studies }\end{array}$ & 1.74 & 0.94 & LE & 1.60 & 0.90 & LE & 1.67 & 0.92 & $\mathrm{LE}$ \\
\hline 3 & $\begin{array}{l}\text { Chalkboard is provided and } \\
\text { always ready for use by social } \\
\text { studies teacher }\end{array}$ & 3.45 & 0.83 & GE & 3.55 & 0.90 & GE & 3.50 & 0.86 & GE \\
\hline 4 & $\begin{array}{l}\text { Resource persons are invited to } \\
\text { create awareness of skills to } \\
\text { operate DVD }\end{array}$ & 1.90 & 0.80 & LE & 1.76 & 0.87 & LE & 1.83 & 0.83 & LE \\
\hline 5 & $\begin{array}{l}\text { Sufficient computers are provided } \\
\text { and used in schools to present } \\
\text { important features in social studies }\end{array}$ & 1.93 & 0.76 & LE & 1.50 & 0.87 & LE & 1.71 & 0.81 & $\mathrm{LE}$ \\
\hline 6 & $\begin{array}{l}\text { Film strip projector is provided for } \\
\text { teaching social studies }\end{array}$ & 1.82 & 0.73 & LE & 1.46 & 0.62 & LE & 1.64 & 0.67 & $\mathrm{LE}$ \\
\hline 7 & $\begin{array}{l}\text { Social studies teachers use power } \\
\text { point to present important features } \\
\text { social studies teaching and } \\
\text { learning }\end{array}$ & 1.97 & 0.76 & LE & 1.45 & 0.55 & LE & 1.71 & 0.67 & LE \\
\hline 8 & $\begin{array}{l}\text { Video clips are prepared and used } \\
\text { to teach certain topics in social } \\
\text { studies }\end{array}$ & 1.93 & 0.74 & $\mathrm{LE}$ & 1.73 & 0.89 & LE & 1.83 & 0.81 & $\mathrm{LE}$ \\
\hline 9 & $\begin{array}{l}\text { Wall charts are made available for } \\
\text { social studies lesson }\end{array}$ & 3.02 & 0.96 & GE & 2.55 & 1.05 & GE & 2.78 & 1.00 & GE \\
\hline 10 & $\begin{array}{l}\text { Text books are always available } \\
\text { for use by social studies teachers }\end{array}$ & 3.60 & 0.69 & GE & 3.10 & 0.85 & GE & 3.35 & 0.87 & GE \\
\hline & $\begin{array}{l}\text { Grand Mean and Standard } \\
\text { Deviation }\end{array}$ & 2.29 & 0.80 & $\mathbf{L E}$ & 2.03 & 0.85 & LE & 2.16 & 0.82 & LE \\
\hline
\end{tabular}

$\mathrm{SD}=$ Standard deviation; $\mathrm{DEC}=$ Decision; $\mathrm{VGE}=$ Very great extent; $\mathrm{GE}=$ Great extent; LE $=$ Low extent; VLE $=$ Very low extent 
The results in Table 1 show that the grand mean and standard deviation of teachers in urban schools were 2.29 and 0.80 respectively while those in rural schools were 2.03 and 0.85 respectively. The mean ratings were all less than the cut - off point of 2.50 except for items 3,9 and 10. The result was considered to be a low extent. The overall grand mean was 2.16 with a standard deviation of 0.82 . This implies that teachers in urban and rural schools were provided with instructional media for the implementation of social studies curriculum to a low extent.

Research Question 2: To what extent do teachers in urban and rural secondary schools employ innovative instructional methods in the implementation of social studies curriculum?

Table 2. Mean Ratings and standard deviation of teachers on the extent to which they employ innovative instructional methods in the implementation of social studies curriculum $(\mathrm{N}=339)$

\begin{tabular}{|c|c|c|c|c|c|c|c|c|c|c|}
\hline $\mathbf{S} / \mathbf{N}$ & Item statements & & Urba & & & Rura & & & Over & \\
\hline & & Mean & SD & Dec & Mean & SD & Dec & Mean & SD & Dec \\
\hline 1 & $\begin{array}{l}\text { Social studies teachers always } \\
\text { use problem solving method in } \\
\text { teaching and learning }\end{array}$ & 3.00 & 0.90 & GE & 2.26 & 0.90 & LE & 2.63 & 0.90 & GE \\
\hline 2 & $\begin{array}{l}\text { Social studies teachers use } \\
\text { corporative learning strategies } \\
\text { in teaching social studies }\end{array}$ & 3.11 & 0.85 & GE & 2.34 & 0.88 & LE & 2.72 & 0.86 & GE \\
\hline 3 & $\begin{array}{l}\text { Social studies teachers often } \\
\text { use simulation method in } \\
\text { teaching social studies }\end{array}$ & 3.01 & 0.95 & GE & 2.29 & 1.00 & $\mathrm{LE}$ & 2.65 & 0.97 & GE \\
\hline 4 & $\begin{array}{l}\text { Social studies teachers use } \\
\text { inquiry or discovery method in } \\
\text { teaching social studies }\end{array}$ & 2.83 & 1.02 & GE & 2.35 & 1.04 & $\mathrm{LE}$ & 2.59 & 1.03 & GE \\
\hline 5 & $\begin{array}{l}\text { Social studies teachers use role } \\
\text { Playing in teaching social } \\
\text { studies }\end{array}$ & 3.18 & 0.83 & GE & 2.56 & 1.00 & GE & 2.87 & 0.91 & GE \\
\hline 6 & $\begin{array}{l}\text { Social studies teachers use } \\
\text { concept mapping to teach } \\
\text { some concepts in social } \\
\text { studies content } \\
\text { implementation }\end{array}$ & 3.16 & 0.85 & GE & 2.26 & 0.91 & $\mathrm{LE}$ & 2.71 & 0.88 & GE \\
\hline 7 & $\begin{array}{l}\text { Social studies teachers } \\
\text { incorporate classroom } \\
\text { discussion in teaching social } \\
\text { studies }\end{array}$ & 3.05 & 0.94 & GE & 2.18 & 0.85 & $\mathrm{LE}$ & 2.61 & 0.89 & GE \\
\hline 8 & $\begin{array}{l}\text { Social studies teachers expose } \\
\text { students to field work in } \\
\text { teaching social studies }\end{array}$ & 2.53 & 0.97 & GE & 1.93 & 0.90 & $\mathrm{LE}$ & 2.23 & 0.93 & LE \\
\hline 9 & $\begin{array}{l}\text { Social studies teachers } \\
\text { encourage learning by doing in } \\
\text { social studies with project } \\
\text { writing }\end{array}$ & 3.15 & 0.86 & GE & 2.20 & 1.13 & LE & 2.67 & 0.99 & GE \\
\hline \multirow[t]{2}{*}{10} & $\begin{array}{l}\text { Social studies teachers use } \\
\text { computer assisted instruction } \\
\text { in teaching }\end{array}$ & 2.10 & 0.77 & LE & 1.30 & 0.46 & $\mathrm{LE}$ & 1.70 & 0.61 & LE \\
\hline & $\begin{array}{l}\text { Grand Mean and Standard } \\
\text { Deviation }\end{array}$ & 2.91 & 0.89 & GE & 2.16 & 0.90 & $\mathbf{L E}$ & 2.53 & 0.90 & GE \\
\hline
\end{tabular}

$\mathrm{SD}=$ Standard deviation; $\mathrm{DEC}=$ Decision; VGE $=$ Very great extent; GE $=$ Great extent; LE $=$ Low extent; VLE $=$ Very low extent 
The results of data analysis in table 2 presents the mean ratings and standard deviation of teachers in urban and rural secondary schools on their use of innovative instructional methods in the implementation of social studies. Items $1-$ 9 in the urban area had mean ratings of 3.00, 3.11, 3.01, 2.83, 3.18, 3.16, 3.05, 2.53, and 3.15 respectively. These mean ratings were higher than the cut - off point of 2.50 except for item 10 that had mean of 2.10 . This result indicates that teachers in urban schools employ innovative teaching methods, to a great extent. Teachers in the urban schools had grand mean score of 2.91 and standard deviation of 0.89 . Teachers in the rural schools had mean ratings of 2.16 and standard deviation of 0.90 . The overall value for the grand mean was 2.53 with standard deviation of 0.90. The result implies that teachers in urban and rural secondary schools employ innovative teaching methods in the implementation of social studies curriculum to a great extent.

Hypothesis 1: There is no significant difference in the mean ratings of teachers in urban and rural secondary schools on the extent to which they provided instructional media for the implementation of social studies curriculum.

Table 3. $\mathrm{t}$ - test analysis of responses of teachers in urban and rural secondary schools on the extent to which they are provided with instructional media for the implementation of social studies curriculum

\begin{tabular}{llllllll}
\hline Location & $\mathbf{N}$ & Mean & SD & t - cal & Df & Sig. & Dec. \\
\hline Urban & 209 & 2.295 & 0.80 & 2.431 & 337 & 0.016 & S \\
\hline Rural & 130 & 2.034 & 0.859 & & & & \\
\hline
\end{tabular}

Table 3 shows that $\mathrm{t}$ - value for the difference in mean ratings of teachers in urban and rural secondary schools on the extent to which they are provided with instructional media for the implementation of social studies curriculum is 2.431 at 0.05 level of significance and 337 degree of freedom. This is significant at 0.016 level of significance, since it is less than the significant level of 0.05 set for the study. The null hypothesis is therefore, rejected. Hence, there is a significant difference in the mean ratings of teachers in urban and rural secondary schools on the extent to which they provided instructional media for implementation of social studies curriculum.

Hypothesis 2: There is no significant difference in the mean ratings of teachers in urban and rural secondary schools on the extent to which they employ innovative instructional methods in the implementation of social studies curriculum.

Table 4. $\mathrm{t}$ - test analysis of responses of teachers in urban and rural secondary schools on the extent to which they employ innovative instructional methods in the implementation of social studies curriculum

\begin{tabular}{llllllll}
\hline Location & N & Mean & SD & t- cal & Df & Sig. & Dec. \\
\hline Urban & 209 & 2.912 & 0.894 & 3.526 & 337 & 0.010 & S \\
\hline Rural & 130 & 2.167 & 0.907 & & & & \\
\hline
\end{tabular}

Table 4 shows that the $\mathrm{t}$ - value for the difference in mean ratings of teachers in urban and rural schools on the extent to which they employ innovative teaching methods in the implementation of social studies programme is 3.526 at 0.05 level of significance and 337 degree of freedom. This is significant at 0.010 level of significance, since it is less than the significant level of 0.05 set for the study. Therefore, the null hypothesis is rejected. Hence, there is a significant difference in the mean ratings of teachers in urban and rural secondary schools on the extent to which they employ innovative teaching methods in the implementation of social studies programme.

\section{Discussion of Results}

Result in Table 1 shows that teachers in urban and rural schools were provided with instructional media for the implementation of social studies curriculum to a very low extent. This finding revealed that the role of instructional media in improving the quality of social studies teaching and learning was grossly neglected. The result obtained may have been influenced by a lot of factors. Firstly, it could be that there was not proper information or coordination on how instructional media should get to the schools. In other word, there could be lack of proper supervision and monitoring of teaching activities. It could also be that government did not provide instructional media in urban and rural schools. This finding is not plausible to the government and stakeholders in the educational system in Enugu State. Furthermore, the $\mathrm{t}-$ test analysis showed that significant difference existed in the mean 
ratings of teachers in urban and rural secondary schools on the extent to which they are provided with instructional media for the implementation of social studies curriculum.

The findings of this study also agreed with Eya and Ureme (2011) who identified that unavailability of instructional materials is still a big challenge in teaching social studies. This finding is also similar to the result of Akubue (2010) that very few instructional materials were available for teaching social studies. It is obvious that teachers not being provided with enough instructional media could be detrimental to effective implementation of social studies in urban and rural schools. This finding was at variance with that of Nwaubani, Otoh - Offong, Usulor and Okeke (2016) who found in their study that substantial number of recommended instructional resources for teaching junior secondary curriculum was available. The study commended the government and stakeholders in education for their efforts to make instructional resources available in schools. Finding of Igba (2009) and submission of Ololobou (2010) confirmed that instructional materials promote teaching and learning. This implies that lack of it could negatively influence the outcome of social studies teaching and learning.

Findings from the analysis shows that teachers in urban secondary schools employed innovative instructional methods to a great extent while those in rural schools employed innovative teaching methods in the implementation of social studies curriculum to a low extent. The findings obtained with respect to teachers' use of innovative teaching methods showed that teachers in the rural schools may not have been exposed to innovative teaching methods and as a result, they were not incorporating them in their teaching. Furthermore, the $t-$ test analysis showed that there was a significant difference in the mean ratings of teachers in urban and rural secondary schools on the extent to which they employ innovative teaching methods in the implementation of social studies curriculum. This result implies that there is disparity in the use of innovative methods among teachers in urban and rural schools.

The findings of the present study concerning non use of innovative teaching methods by teachers in rural schools is in agreement with the work of Okobia (2016) who found that a great number of the social studies teachers were not using the suitable teaching methods in the classroom. Okobia further submitted that social studies teachers should utilize in their interactive process, methods such as simulation games, inquiry, problem solving, discovering, role playing, which are indispensable for the successful implementation of the social studies curriculum. Aderina (2014) also pointed out that the teacher of social studies needs to employ varieties to teaching strategies in order to bring about meaningful learning. The above assertion is in consonance with that of Narayanan (2017) who discovered that creativity and innovative teaching methods help to clear concepts to learners, arouse student's interest in classroom, imprint lasting memory and enhance learner's academic performance.

\section{Conclusion and Recommendation}

From the findings and discussion of the study, it is clear that social studies curriculum has not been effectively implemented. There were lapses and challenges being encountered in the course of its implementation. The study reports poor provision of instructional media both in the urban and rural schools. This implies that teachers were not adequately provided with supportive media aimed at improving quality of teaching and learning. Inadequate provision of instructional media could negatively affect the effective implementation of social studies curriculum. The importance of instructional media is enormous and lack of them would deprive both the teachers and the students of effective teaching and learning. Equally, worthy of note is that teachers in the rural schools did not employ innovative teaching methods. This may be as a result of poor knowledge of the use of innovative methods or lack of commitment on the part of these teachers. The innovative approach to instruction using modern teaching methods such as inquiry, discussion, simulation game, problem solving, project, discovery, role playing and others would help students to achieve the intended social studies objectives. The reasons among others, of incorporating innovative teaching methods to teaching and learning is to bring learning closer to students, make learning interesting, enable the students deal with their academic problems and to make learning flexible, activity oriented to fit into students' real-life experiences.

The findings of this study provide empirical evidence to support the claim of lacking facilities and the difficulties social studies teachers and students face in teaching in schools. It would be a useful evidence for teachers to press home their demands at the ministries of education. Consequently, some teaching - learning problems would be solved when policy makers are well informed through this study. It would give them more concrete information on how curriculum implementers are carrying out their responsibilities and to serve as a guide in deciding whether to effect a change, innovate or improve the existing social studies teaching plan.

The study recommends that efforts should be made by school administrators to expose teachers to workshops on innovative methods of teaching and the use of instructional media. When teachers are provided with modern 
instructional media, learning will be more meaningful. Therefore, principals of schools should monitor the teaching of social studies, with a bid to ensure use of provided instructional media and innovative instructional strategies.

\section{Acknowledgements}

The actualization of this work was with enormous contribution and encouragement extended by two important personalities who cannot be possibly avoided. Firstly, the lead researcher appreciates Prof. D.U. Akubuilo of Enugu State University of Science and Technology, Enugu state for her intellectual input and advice during the course of this research. Also, the lead researcher is grateful to Dr. M.E. Ikehi of the University of Nigeria, Nsukka for being a great motivator, academic mentor, and always ready to help with ideas and proof reading.

\section{References}

Adeniran, A. A. (2014). Students centred teaching methods and utilization of instructional strategies for effective social studies teaching. A paper presented at the $58^{\text {th }}$ World Assembly of the International Council of Education for teaching, (ICET) at the University of Ontario Institute of Technology Oschacma, Ontario Canada $15^{\text {th }}-20^{\text {th }}$ June, 2014.

Ajewole, G. A. (2005). Fundamental of curriculum and instruction. Lagos: Raytel Communication Ltd.

Akubue, F. N. (2010). Use of instructional materials for teaching social studies in junior secondary schools. The Nigerian Journal of Research and Production. Retrieved from https://www.acdemia.edu/24917054/use_of_instructional_materials_for_teaching_socialstudies_in_junior_seco ndary_schools

Arthur, C. A. (2012). Implementation of core English language programme in the senior secondary schools in Ghana. The case of some selected schools in the Ashani Region. Master's Dissertation. University of Cape Coast.

Daddad, M. M., Agbaba, L. O., Suberu, A., Danjuma, A., Patricia, H. A., Idris, A., ... Murtala, M. (2019). availability and utilization of instructional materials in a North - West school of nursing, Nigeria. International Journal of Medical Science and Applied Biosciences, 1(4), 2545-5803.

Dhandhania, T. (2016). The importance of social studies in the school curriculum. The Progressive Teacher.

Edinyang, S. D., \& Effiom, N. V. (2017). Social Studies Teaching Resources in the $21^{\text {st }}$ century. International Journal of Sociology and Anthropology Research, 3(4), 8-14.

Eya, P. E., \& Ureme, C. M. E. (2011). Availability and utilization of instructional materials for social studies in junior secondary schools in Enugu. The Nigerian Journal of Research and Production. Retrieved from https://files.eric.ed.gov/fulltext/EJ1099475.pdf

Federal Republic of Nigeria. (2013). National policy on Education (6th ed.) Lagos: NERDC press.

Igba, D. I. (2009). Indispensability of instructional materials in the implementation of teacher education programmes. Journal of Arts and Social Science Education, 1(1), 24-34.

Inyang-Abai, E. (2004). Curriculum technologies for basic education: methods, media and their utilization. Calabar: MIFAM Services Nigeria Ltd.

Mezieobi, D. I. (2007). Preparing the primary school social studies teacher for the challenge of the 21st century. Nigerian Journal of Curriculum Studies, 14(3), 78- 86.

Mezieobi, D. I., \& Onyeanusi, O. C. (2012). Repositioning social studies education in Nigeria tertiary institutions for the attainment of vision 20-20 - 20 in Nigeria. Journal of Social Studies, 15(1), 246-256.

Mezieobi, K. A. (2008). Social Studies in Nigeria: Teaching Methods, Instructional Materials and Resources. Owerri: Nigeria Acada Peak.

Mezieobi, K. A., Fubara, V. R., \& Mezieobi, S. A. (2013). Social studies in Nigeria. Teaching methods. Instructional materials and resources. Owerri: Academic publisher.

Narayanan, S. (2017). A study on the Relationship between creativity and Innovation in Teaching and Learning Methods towards students' academic performance at private higher education institution, Malaysia. International Journal Academic Research in Business and Social Science. https://doi.org/10.6007/IJARBSS/v7i14/3647

National Council of the Social Studies. (2004). Expectations of excellence: Curriculum standards for social studies. Washington, D. C: NCSS Press. 
Nigerian Educational Research and Development Council. (2013). Teachers' guide for the revised 9 - year basic education curriculum (BEC) religion and national values social studies. Abuja: NERDC Press.

Nwaubani, O. O., Otoh - Offong, A. N., Usulor, V. I., \& Okeke, J. N. (2016). Teacher qualification as a factor in the utilization of Instructional facilities for effective implementation of social studies curriculum in Ebonyi State, Nigeria. Journal of Applied Sciences Research, 12(7), 21-28.

Ogakwu, V. N. (2010). Enhancing human capital development through a dynamic education system. Lit Academic Journal, 1(2), 104-113.

Okebaram, S. M. (2014). Research methodology for business and social sciences: An expository viewpoint. Enugu, John Jacob's Classic Publishers.

Okobia, E. O. (2016). An assessment of teaching methods used by social studies teachers in junior secondary schools in Edo State, Nigeria. Educational Research International, 5(2), 32-43.

Okogu, J. (2011). Factors affecting the effective implementation of social studies curriculum in Delta State teachers training colleges. Journal of Research in Education and Society, 2(3), 26-39.

Olalobou, E. P. (2010). Instructional materials, production in a challenging educational system. A paper presented at an Annual National Conference Organized by the Curriculum. Development Materials Centre (CUDMAC) University of Nigeria, Nsukka.

Onyeanusi, O. C. (2016). Democracy and nation building. In D. I Mezieobi (Ed.), Nigerian Perspective. Onitsha Bel's Book.

Osuala, E. C. (2007). Introduction to research methodology. Onitsha: African - FEP Publishers. 